\title{
Orange Juice Processing Waste As a Biopolymer Base For Biodegradable Film Formation Reinforced With Cellulose Nanofiber and Activated With Nettle Essential Oil
}

\section{Seyedeh Elham Mousavi Kalajahi}

Islamic Azad University Tabriz Branch

Ainaz Alizadeh ( $\sim$ ainaz_alizadeh@hotmail.com )

Islamic Azad University Tabriz Branch https://orcid.org/0000-0002-9685-9164

Hamed Hamishehkar

Tabriz University of Medical Sciences

Hadi Almasi

Urmia University

Narmela Asefi

Islamic Azad University Tabriz Branch

\section{Original Research}

Keywords: cellulose nanofiber, nano biocomposite film, nettle essential oil, orange waste

Posted Date: February 9th, 2021

DOI: https://doi.org/10.21203/rs.3.rs-169308/v1

License: (c) (1) This work is licensed under a Creative Commons Attribution 4.0 International License.

Read Full License 


\section{Abstract}

Concerns about environmental problems have led to the development of biodegradable packaging. Food wastes as a byproduct could be a good source for biopolymers. This study described the physical and antimicrobial features of nano biocomposite films based on orange waste powder (OWP) with different concentrations of nettle essential oil (NEO) (1.5 and $3 \%$ ) as an antibacterial agent and cellulose nanofiber (CNF) (3 and $6 \%$ ) as a structural reinforcement. Thus, tensile strength, elongation at break, water vapor permeability, FE-SEM, FTIR, XRD, DSC, and antimicrobial properties were investigated. As a result, adding CNF improved the tensile strength and water barrier properties of the samples. Compared to the control film, adding NEO (3\%) decreased the tensile strength but increased water vapor permeability and melting temperature. Moreover, the OWP film samples had an antimicrobial effect against five foodborne pathogens. Although, adding NEO increased antimicrobial properties, adding CNF did not exhibit antimicrobial effects. Consequently, orange waste could be used to produce an active film with improved physicomechanical and antibacterial properties by incorporating CNF and NEO.

\section{Introduction}

Food packaging materials are almost petroleum-based plastics that are widely used due to their availability, low price, and desirable properties. However, petroleum-based plastics cause many environmental problems due to their non-biodegradability [1-3]. Furthermore, the migration of some compounds such as plasticizers, monomers, and solvent residues from plastics into the food leads to offflavor and reduce food safety[4]. Concerns about the health problems related to plastics and consumer's demand for high-quality food products have led to developing biodegradable packaging materials such as films and coatings $[5,6]$. In recent years, various biopolymers such as proteins and polysaccharides have been used to develop biodegradable films to replace synthetic plastics and prevent spoilage and microbial contamination of fruits and vegetables during storage as well as acting as a carrier of functional compounds such as antimicrobials, antioxidants, flavorings, and colors [6-8]. Additionally, fruit and vegetable puree has been widely used as a biopolymer source to produce edible films [9].

According to the previous studies, different fruit purees such as peach puree [10], apple puree [11], banana puree [12], mango puree [13,14], and carrot puree [15] were successfully utilized to develop edible films. Although the land has been dedicated to fruit and vegetable as a biopolymer source for the production of food packaging is negligible, the use of bio-based and biodegradable raw materials with no land uses is important [16]. In this regard, wastes from food plants are the best source to produce biopolymers due to their low cost and vast availability [17]. Accordingly, orange production is estimated at 85 million tons annually and industrial processing of orange like orange juice production results in 50$60 \%$ waste of the raw material [18]. Orange waste has a considerable amount of soluble solids, water, and $\mathrm{pH}$ 3-4 that could cause serious environmental problems when maintenance improperly [19]. Moreover, the orange waste contains pectin, soluble sugars, hemicellulose, cellulose, starch, protein, lignin, ash, fat, and flavonoids, which indicates the importance of its recycling process $[16,17,20]$. In this regard, a recent survey on Lemon waste showed successful results for film formation [21]. However, the 
results of previous studies also showed that low molecular weight compounds existence in fruit and vegetable puree prevent the formation of a continuous film network [22].

Nano-based filler compounds such as nanoclay, nanometals, and cellulose nanofibers were utilized to improve the physical, mechanical, and gas inhibitory properties of edible films [23, 24]. Cellulose nanofiber is one of the nanoparticles that were proposed as a reinforcement agent in recent years. Cellulose nanofibers have high chemical and thermal stability compared to other organic nanoparticles. They are used to increase mechanical strength, thermal resistance, inhibition against gases, transparency, water barrier properties, and improved film appearance [5, 6, 22]. Moreover, cellulose nanofiber provided controlled release of active compounds as well as the formation of a complex diffusion pathway due to the impermeability of nanofillers [23]. Accordingly, packaging films can also act as carriers of antioxidant, antimicrobial, and active compounds to control pathogens and improve the quality and the shelf life of food [11]. Nettle (Urtica dioica L.) essential oil, belongs to the nettle family and it is widely known as a medicinal plant and food additive. Nettle has a vast nutritional value, and its high antimicrobial properties are related to carvacrol, which has significant antibacterial, antiviral, antifungal, and antiparasitic effects [25].

Orange processing in many countries which produces abundant wastes with very low cost, could be used for film formation and improved with other materials to show better film properties. To the best of our knowledge, no previous studies were done on preparing a bioactive film from orange waste in combination with other reinforcing materials or active agents. Therefore, the aim of the present study was to evaluate the feasibility of producing nanobiocomposite film based on orange juice processing waste containing cellulose nanofiber and nettle essential oil.

\section{Materials And Methods}

\subsection{Materials}

Oranges waste (obtained from orange juice production) was procured from Takdaneh Industry Co. (Marand, Iran). Nettle essential oil (NEO) was purchased from Tabibdaru Industry Co. (Kashan, Iran). Calcium sulfate, magnesium nitrate, potassium sulfate, citric acid (monohydrate, >99.5), and glycerol were obtained from Merck Co. (Darmstadt, Germany). CNF (with an average diameter and length of about $35 \mathrm{~nm}$ and $5 \mu \mathrm{m}$, respectively, and purity of $99 \mathrm{~g} / 100 \mathrm{~g}$ ) was procured from Nano Novin Polymer Co. (Saari, Iran). Listeria monocytogenes (PTCC 1298), Salmonella enterica (PTCC CiP104115), Pseudomonas aeruginosa (PTCC 1310), Staphylococcus aureus (PTCC 1764), and Escherichia coli (PTCC 1163) were prepared from Persian Type Culture Collection (PTCC) (Tehran, Iran). Muller-Hinton agar for the microbiological test was obtained from Sigma-Aldrich (St. Louis, USA).

\subsection{Preparation of orange waste powder (OWP)}

Orange waste obtained from juice extraction was processed according to the method described by Batori et al. (2017) with some modifications [16]. Briefly, orange waste was first washed with water to remove 
dissolved sugars. For this purpose, orange waste was soaked in water for $24 \mathrm{~h}$. Consequently, two further washing steps were applied and each step consisted of stirring (at $115 \mathrm{rpm}$ ) the orange waste immersed in the water bath at $35^{\circ} \mathrm{C}$ for $20 \mathrm{~min}$. The ratio of water to orange waste was 1.5:1 in all stages. After draining, the orange waste was collected and dried in the oven (UF 55, Memmert, Germany) at $40{ }^{\circ} \mathrm{C}$ for $16 \mathrm{~h}$. Consequently, the dried waste was finely milled and used to prepare the film samples.

\subsection{Preparation of nanobiocomposite OWP based films}

The OWP-based nanobiocomposite film samples were prepared according to the methods of Batori et al, (2017) with some modifications and were coded as Table 1. The film solutions were prepared by incorporating OWP ( $6 \% \mathrm{w} / \mathrm{v}$ ) and CNF ( 3 and $6 \% \mathrm{w} / \mathrm{w}$ based on OWP weight) in an acidic aqueous solution. The mentioned acidic solution was prepared with $1 \%(\mathrm{w} / \mathrm{v})$ citric acid and $7 \%(\mathrm{w} / \mathrm{w}$ based on solution weight) glycerol as a plasticizer. Additionally, sonication (UP200H, Hielscher, Teltow, Germany) was utilized (frequency of $40 \mathrm{kHz}$ for $10 \mathrm{~min}$ ) before the inclusion of CNF solution to obtain a homogeneous and uniform dispersion of CNF particles with less aggregation. Afterward, the prepared suspension was blended by using a magnetic stirrer at $115 \mathrm{rpm}$ for $30 \mathrm{~min}$ in a water bath at $70{ }^{\circ} \mathrm{C}$ and then filtered to remove the large particles. Nettle essential oil (NEO) (1.5 and 3\% w/w based on OWP weight), as an antimicrobial agent, was incorporated in the filtered solution after the temperature of film solutions was reduced to room temperature.

Consequently, the prepared solution was homogenization (IKA T25-Digital Ultra Turrax, Staufren, Germany) at $13500 \mathrm{rpm}$ for $3 \mathrm{~min}$ and treated by ultrasound at $40 \mathrm{kHz}$ for $20 \mathrm{~min}$ to eliminate the dissolved and undesired air bubbles (degassing operation). Furthermore, OWP-based film without CNF and essential oil incorporation was produced as a control sample for later analyses. Finally, the solutions were cast on the polystyrene plates and dried at $35^{\circ} \mathrm{C}$ for $36 \mathrm{~h}$. Moreover, obtained film samples were conditioned in a desiccator with $53 \%$ relative humidity $(\mathrm{RH})$ by using saturated magnesium nitrate solution at $25^{\circ} \mathrm{C}$ for $36 \mathrm{~h}$.

\subsection{Characterization of films}

\subsubsection{Fourier transforms infrared (FT-IR)}

FT-IR spectroscopy (Tensor27, Bruker, Etlingen, Germany) was used to study the structural interactions of nanocomposite film samples. The spectra were obtained at the wavenumber range of $4000-400 \mathrm{~cm}^{-1}$ with a resolution of $4 \mathrm{~cm}^{-1}$. The samples were prepared according to the $\mathrm{KBr}$-pellet method.

\subsubsection{Field emission scanning electron microscopy (FE-SEM)}

The surface and cross-sectional surface of the film samples were morphologically studied using FE-SEM (Sigma VP, Zeiss, Obercochen, Germany) after the gold coating of the samples (DST1, nanostructured coating, Tehran, Iran).

\subsubsection{X-ray diffraction $(X R D)$ analyses}


The x-ray diffractometer (Model Kristalloflex D500, Siemens, Munchen, Germany) in the diffraction angles (29) of $5-40^{\circ}$ at room temperature was used to obtain the XRD images. To analyze the XRD spectra a Cu Ka radiation source $(\mathrm{k}=0.154 \mathrm{~nm}, 40 \mathrm{kV}$ and $40 \mathrm{~mA})$ was used.

\subsubsection{Differential scanning calorimetry (DSC)}

The thermal properties of film samples were evaluated using the DSC test (DSC400 SANAF, Tehran, Iran). In brief, $20 \pm 5 \mathrm{mg}$ of each sample was weighed in the sample pan and an empty pan was considered as a reference. The operation was performed in -100 to $250{ }^{\circ} \mathrm{C}$ at a rate of $10{ }^{\circ} \mathrm{C} / \mathrm{min}$ to determine the glass transition temperature $(\mathrm{Tg})$ and melting temperature $\left(\mathrm{T}_{\mathrm{m}}\right)$ of the samples.

\subsubsection{Mechanical properties}

In order to study the mechanical properties of film samples, a Tensile Analyzer (DBBP-20, Bongshin, Seongnam, Korea) was used. The film samples were cut in the form of dumbbells $(8 \mathrm{~cm} \times 0.5 \mathrm{~cm})$ and mounted in two grips at $50 \mathrm{~mm}$. A $10 \mathrm{~mm} / \mathrm{min}$ crosshead speed was considered. The mechanical parameters of the samples including elongation to break (ETB) and ultimate tensile strength (UTS) were determined [5].

\subsubsection{Water vapor permeability (WVP)}

To determine the water vapor permeability of the film samples the ASTM E96-05 standard method was used (ASTM, 2005). Film samples were sealed in glass vials with $0 \% \mathrm{RH}$ and placed in a desiccator with $97 \% \mathrm{RH}$ at $25^{\circ} \mathrm{C}$. The vials were weighed every $24 \mathrm{~h}$. The changes in weight were recorded versus time and the slope was calculated by linear regression. The water vapor transmission rate (WVTR) was defined as the slope of the linear part of the curve $(\mathrm{g} / \mathrm{h})$ divided by the transfer area $\left(\mathrm{m}^{2}\right)$. Finally, after sealing the film samples in glass vials at $0 \otimes R H$, they were placed in a desiccator at $97 \otimes R H$ and $25{ }^{\circ} \mathrm{C}$. The weight of the vials was checked every $24 \mathrm{~h}$. Curves of weight changes versus time were plotted and the slope was determined using linear regression. The water vapor transmission rate (WVTR) was calculated by dividing the slope of the linear part of the curve (grams per hour) by the transfer area $\left(\mathrm{m}^{2}\right)$ and the WVP $\left(\times 10^{-7} \mathrm{gPa}^{-1} \mathrm{~h}^{-1} \mathrm{~m}^{-1}\right)$ of film samples was calculated as follows:

$$
W V P=\frac{W V T R \times X}{P\left(R_{1}-R_{2}\right)}
$$

So that, $\mathrm{P}$ shows the saturation vapor pressure of water $(\mathrm{Pa})$ at $25^{\circ} \mathrm{C}, \mathrm{R}_{1}$ is the desiccator $\mathrm{RH}, \mathrm{R}_{2}$ is the vial $\mathrm{RH}$ and $\mathrm{X}$ indicates the film average thickness $(\mathrm{m})$.

\subsubsection{Antibacterial activity}

The antimicrobial effect of the film samples on some food-borne pathogenic bacteria, L. monocytogenes, $S$. enterica, P. aeruginosa, $S$. aureus, and $E$. coli. was investigated according to the agar disc diffusion 
method After preparing suspensions of $1.5 \times 10^{8} \mathrm{CFU} / \mathrm{mL}$ bacteria they were cultured on the MullerHinton agar medium. Film samples were prepared in round shapes with a diameter of $7 \mathrm{~mm}$ and placed on the surface of Muller-Hinton agar plates and incubated at $37^{\circ} \mathrm{C}$ for $24 \mathrm{~h}$. A caliper was used to determine the inhibition zone around the film sample and the mean values were reported [1].

\subsection{Statistical analysis}

All the analyses were done in triplicate and the statistical evaluation of the data was conducted using a one-way analysis of variance (ANOVA) (IBM Corporation, Armonk, NY, USA). To determine the significant differences among the treatment means, Duncan's multiple test range $(p \otimes 0.05)$ was used. The reports show the means of the results.

\section{Results And Discussion}

\subsection{Fourier transforms infrared (FT-IR) spectroscopy}

ATR-FTIR spectra have been used to monitor intermolecular interactions and structural changes within the film matrix. Figure 1 shows the FT-IR spectrum of OWP/CNF0\%/NEO0\%, OWP/CNF6\%/NEO0\%, OWP/CNF0\%/NEO3\% and OWP/CNF6\%/NEO3\% film samples. The spectrum of OWP/CNF0\%/NEO0\% film sample showed several specified peaks which were summarized as follows: 1) Peaks ranging 3117$3842 \mathrm{~cm}^{-1}$ indicated intermolecular $\mathrm{O}-\mathrm{H}$ stretching vibration bonds of the pectin monomer, the symmetric and asymmetric stretching vibration associated with $\mathrm{H}_{2} \mathrm{O}$ [9] and free $\mathrm{N}-\mathrm{H}$ groups of proteins [5]. 2) The peaks around $2822-2885 \mathrm{~cm}^{-1}$ associated with $\mathrm{C}-\mathrm{H}$ bonds of the methylene group in the polymer structure and stretching vibrations of the methyl group of galacturonic acid methyl ester $[8,26]$. 3) The peaks ranging from 1883-1990 $\mathrm{cm}^{-1}$ belonged to the $\mathrm{C}-\mathrm{H}$ groups of aromatic compounds. 4) The peaks at 1741 $\mathrm{cm}^{-1}$ associated with the $\mathrm{C}=0$ groups of the ester bands $[8,26]$, which could be related to carbonyl esters [27] or phenolic esters groups, due to the existence of the orange natural essential oil in OWP. 5) The peaks ranging from $1647-1693 \mathrm{~cm}^{-1}$ associated with the symmetric carboxylate and the non-esterified carbonyl groups in galacturonic acid structure $[8,9,26]$. 6) The peak at $1520 \mathrm{~cm}^{-1}$ represented the amide II bands that were associated with bending vibrations of the $\mathrm{N}-\mathrm{H}$ groups and stretching vibration of the $\mathrm{C}-\mathrm{N}$ groups [9]. 7) Absorption bands at 1465, 1417, and $1227 \mathrm{~cm}^{-1}$ were associated with the aliphatic chain bending vibrations [9], asymmetric carboxyl vibrations, [26] and carboxylic acid stretching vibration of C-O groups in pectin, respectively [8]. 8) The peaks at $965 \mathrm{~cm}^{-1}$ belonge to the $\mathrm{C}-0$ bending vibrations of the pectin structure [28]. 9) Peaks ranging $500-850 \mathrm{~cm}^{-1}$ indicated the glycerol adsorption bands [29]. According to the result, the spectrum of OWP/CNF6\%/NEO0\% film sample showed disappearing of the peaks in the range of $2822-2885,1883-1990,1741,1465$, and $417 \mathrm{~cm}^{-1}$. Additionally, incorporating $6 \%$ CNF in OWP based film samples transferred the peak around 1227 to $1126 \mathrm{~cm}^{-1}$, which represented the strong interactions between film components and CNF. In this regard, Zhang et al., (2019), also reported that the transfer of the peaks to a lower wavenumber by incorporating CNF is associated with the formation of stronger interactions between film constituents and CNF [30]. Moreover, the addition of CNF 
led to the transfer of peaks ranges from $513-676 \mathrm{~cm}^{-1}$ to $516 \mathrm{~cm}^{-1}$ and from $3117-3842 \mathrm{~cm}^{-1}$ to 3610 $3810 \mathrm{~cm}^{-1}$, which indicated the elimination of absorption bands in the range of $3117-3500 \mathrm{~cm}^{-1}$ due to the formation of strong hydrogen bands between the film matrix and CNF as well as reduction of free $\mathrm{OH}$ groups. The obtained results were in accordance with previous studies [5, 26, 31]. According to the spectrum of OWP/CNF0\%/NEO3\% film samples, NEO incorporation to the OWP based film samples did not lead to the formation of a new absorption peak. However, the intensities of the peaks had slight differences compared to control film. Furthermore, the inclusion of the NEO increased the intensities in most peaks that were associated with the increase of free functional groups as a result of the existence of essential oil molecules in the polymer matrix, which limited the formation of interactions [26]. According to the results, incorporation of $6 \% \mathrm{CNF}$ and $3 \%$ NEO in the OWP-based film sample in combination had led to shift the peak from 965 and $1227 \mathrm{~cm}^{-1}$ to $843-1062$ and $1159-1251 \mathrm{~cm}^{-1}$, respectively. Moreover, the peaks at $1833-1990$ and $2822-2885 \mathrm{~cm}^{-1}$ were shifted to 1918 and $2929 \mathrm{~cm}^{-1}$, respectively. Furthermore, the wavenumbers of the peaks range from $3117-3842 \mathrm{~cm}^{-1}$ were shifted to $3442-3842 \mathrm{~cm}^{-1}$ as well as disappearing the peaks around $3117-3300 \mathrm{~cm}^{-1}$ which was due to the formation of strong hydrogen bonds between the film components, NEO and CNF, and reduction of free $\mathrm{OH}$ groups consequently.

\subsection{Field emission scanning electron microscopy (FE-SEM)}

Scanning electron microscopy (SEM) was used to investigate the morphology of the film and study the distribution of components in the film matrix. The microstructure of OWP based film samples containing different concentrations of CNF and NEO was studied to understand the distribution of essential oil droplets and cellulose nanoparticles in the biopolymer matrix and its possible effects on film properties (Fig. 2). The surface micrograph displays a heterogeneous and rough surface of the films prepared from OWP, which was common in films produced from more than one component, such as films made from fruit puree due to the existence of complex compounds like soluble and insoluble polymers [16]. The cross-sectional images of the control film sample also exhibited a rough surface which was consistent with the results obtained from Tulamandi et al. (2016) who studied the films made from papaya puree [9].

According to the surface micrograph, the addition of $6 \%$ CNF led to morphological changes in the films. In this regard, CNF removed surface cracks and created a dense sheet-like structure in the films due to the uniform distribution of CNF in the film matrix and the strong interaction of CNF with pectin chains. Zykwinska et al. (2005), reported that pectin reacts with cellulose nanoparticles by forming hydrogen bonds between the hydrophilic parts of the film and hydroxyl groups of CNF [32]. The findings were in accordance with studies of Shahmohamadi and Almasi (2016), about the structural, physical, and antimicrobial properties of films prepared from bacterial cellulose-containing zinc oxide nanoparticles [33]. According to the surface micrographs, the addition of $3 \%$ NEO to OWP based films changed the structure of the matrix and created a rough and spongy surface.

In this regard, cross-sectional images also showed a rough structure with small holes in some parts of the film. The spongy surface of the film samples containing NEO was associated with the volatility of the 
essential oil presented in the film matrix that created the porosity in the film matrix during the drying process. Similar results have been obtained by other researchers [34-36]. The surface micrograph of the film containing $6 \%$ CNF and $3 \%$ NEO in combination shows the removal of cracks caused by evaporation of essential oil on the film surface, which associated with the formation of the strong bonds between the NEO and CNF that prevents the migration of essential oil to the surface during the drying period. Additionally, the continuous and compact structure shown in cross-sectional images indicated strong interactions between the CNF, NEO, and the film matrix.

\subsection{X-ray diffraction (XRD) analyses}

Figure 3 shows the XRD diffractions of OWP/CNF0\%/NEO0\%, OWP/CNF6\%/NEO0\%, OWP/CNF0\%/NEO3\% and OWP/CNF6\%/NEO3\% film samples. The diffractogram of OWP/CNF0\%/NEOO\% film sample showed three main peaks near at $2 \theta$ of $12^{\circ}, 15^{\circ}$, and $20^{\circ}$ which were indicating the semi-crystalline structure of the OWP based film sample and relatively amorphous structure that indicated the existence of crystalline regions due to hydrogen bonds between the pectin and other components of the film sample [37]. As mentioned, the main compound of OWP was pectin and it was reported that the peaks near at $2 \theta$ of $12.72^{\circ}, 16.30^{\circ}, 18.45^{\circ}, 25.32^{\circ}, 40.14^{\circ}$ were related to the pure pectin crystallinity [26]. The results were in line with the findings of Nisar et al. (2018), who produced a film by using pectin extracted from citrus. Additionally, pure CNF showed a diffraction pattern with three specific peaks at $2 \theta$ of $14.54^{\circ}, 16.92^{\circ}, 22.72^{\circ}$ and the diffraction profiles of spectrum pertaining to the OWP/CNF6\%/NEOO\% showed that the addition of CNF resulted in the removal of the peak at $2 \theta$ of $15^{\circ}$ and exhibiting a new peak at $2 \theta$ of $37^{\circ}$ compared to control film $[26,38,39]$. Moreover, the diffractogram of the OWP/CNF6\%/NEO0\% film sample indicated a uniform distribution with no agglomeration of CNF in the film matrix. Furthermore, the removal of the peaks at $2 \theta$ of $15^{\circ}$ and formation of a new peak at $2 \theta$ of $37^{\circ}$ indicated good compatibility of CNF and pectin as well as the formation of new crystalline regions in amorphous areas. These results were in line with the findings of other authors $[26,40]$.

According to the results, NEO incorporated the OWP-based film sample showed just one peak near $2 \theta$ of $12^{\circ}$, which was due to the existence of NEO in the matrix that increased the mobility of the polymer chain and limited the formation of a crystalline structure $[30,41]$. The diffractogram of OWP/CNF6\%/NEO3\% film sample revealed two peaks near $2 \theta$ of $12^{\circ}$ and $14^{\circ}$ due to the existence of NEO between the pectin and CNF chains and limited the development of the crystalline structure. Furthermore, OWP/CNF6\%/NEO3\% film sample exhibited a better crystalline structure than films containing individual NEO due to the presence of CNF in the film matrix that limited the mobility of polymer chains caused by incorporating NEO.

\subsection{Differential scanning calorimetry (DSC)}

Table 2 displays the thermal properties of OWP-based nanocomposites. DSC thermographs showe two endothermic peaks; the first one indicates the glass transition temperature $\left(T_{g}\right)$ and the second one indicates the melting temperature $\left(T_{m}\right)[42,43]$. According to the results, the $T_{g}$ and melting temperature 
of the OWP/CNF0\%/NEO0\% film sample were $-87.9^{\circ} \mathrm{C}$ and $125.7^{\circ} \mathrm{C}$, respectively. The low $\mathrm{T}_{\mathrm{g}}$ value in OWP based film samples is related to the polymer structure, its internal properties, and hydrophilic nature. Accordingly, water molecules also caused the mobility of polymer chains and led to a reduction of $\mathrm{T}_{\mathrm{g}}$ value due to their lubricating and quasi-plasticizing characteristics.

Moreover, other soluble solid compounds in orange waste, such as sugar with plasticizing effects, led to a decrease in the $T_{g}$ value of these films compared to films prepared from pure pectin. The sub-zero $T_{g}$ value of the produced OWP based films indicated relatively poor chemical stability due to high molecular mobility and consequently high reactivity of the film components. However, the low $T_{g}$ of these films implied optimal flexibility at refrigerator temperatures [26]. According to the results, the incorporation of $6 \% \mathrm{CNF}$ increased the $\mathrm{T}_{\mathrm{g}}$ and $\mathrm{T}_{\mathrm{m}}$ values of OWP-based films to $-86.6^{\circ} \mathrm{C}$ and $152.9^{\circ} \mathrm{C}$, respectively, which could be due to the interactions between pectin and CNF and increasing the film crystallinity. Additionally, the inclusion of CNF in the biopolymer matrix increases the formation of heterogeneous nuclei and facilitates crystallization [44] as well as reduces the free space between the chains and decreases mobility. Furthermore, the interactions of CNF with water molecules led to their redistribution in the biopolymer matrix and reduced the plasticizing effects of water molecules while consequently increasing the $\mathrm{T}_{\mathrm{g}}$ value.

In this regard, Pelissari et al. (2017) reported that the high affinity of glycerol may cause enhancement of $\mathrm{T}_{\mathrm{g}}$ value in the films containing CNF which indicated the migration of glycerol from polymer-rich to CNF containing regions and reduced the plasticizing effect of glycerol [45]. In general, the mentioned results showed the improvement of the inhibitory properties of the films by adding $6 \%$ CNF. Similar results were obtained by other authors $[22,46,47]$. According to the thermographs, the addition of $3 \%$ NEO decreased $\mathrm{T}_{\mathrm{g}}$ and increased $\mathrm{T}_{\mathrm{m}}$ values to -98.9 and $158.0^{\circ} \mathrm{C}$, respectively compared to the control sample. The single glass transition temperature appeared in the thermograph of OWP/CNFO\%/NEO3\% indicated the uniform distribution of NEO molecules in the biopolymer matrix, additionally, the plasticizing effect of the NEO increases the mobility of polymer chains in the amorphous region which led to shifted $T_{g}$ value of the film to lower temperatures, consequently.

This phenomenon revealed that NEO-polymer bonds were weaker than polymer-polymer ones, which led to increased mobility of polymer chains at lower temperatures [48]. On the other hand, the increased melting point of NEO containing samples was due to the high molecular weight and lipophilic nature of essential oil, which were in line with the previous studies [35, 42, 43]. Results also showed that OWP/CNF6\%/NEO3\% film sample exhibited a slight increase in the $\mathrm{T}_{\mathrm{g}}\left(-87.7^{\circ} \mathrm{C}\right)$ and $\mathrm{T}_{\mathrm{m}}\left(126.1^{\circ} \mathrm{C}\right)$ values compared to control film. In other words, the interactions between CNF and NEO reduced the plasticizing effect of essential oil and limited the mobility of biopolymer chains by increasing structural cohesion. Additionally, the increased $T_{g}$ value of this film sample compared to NEO incorporated films indicated that CNF-NEO bonds were stronger than polymer-NEO bonds, which led to a decrease in the mobility of polymer chains. 


\subsection{Mechanical properties}

The evaluated mechanical properties of OWP based film samples containing different concentrations of CNF and NEO are summarized in Table 3 . According to the obtained results, by increasing the concentration of CNF from 0 to $6 \%$, the UTS values of the film samples increased (from $4.88 \pm 0.10$ to $7.66 \pm 0.29 \mathrm{MPa}$ ), and the \% E value decreased (from $32.40 \pm 0.36$ to $20.94 \pm 0.81 \%$ ) significantly $(p<0.05)$. This phenomenon could be due to the uniform distribution of CNF in the film matrix as well as the formation of high interactions between CNF and pectin that reduce the relative mobility of polymer chains and cause stiffer films with less flexibility [49-51].

Additionally, natural strength and rigidity of CNF [52], high density of nanomaterials compared to biopolymer matrix, filling free spaces in amorphous domains, creating a strong network as a result of increasing hydrogen bonds and increasing the crystalline regions of the matrix were the other factors that enhanced the mechanical properties of the CNF incorporated film samples, which were in accordance with previous studies $[8,26,44]$. As found, the mechanical strength of NEO incorporated films decreased significantly $(p<0.05)$ in comparison with the control sample. This phenomenon could be due to the formation of weak biopolymer-NEO interactions compared to the strong biopolymer-biopolymer interactions [53].

Furthermore, increasing the concentration of NEO from 1.5 to $3 \%$, decreased the UTS values of the film samples from $4.38 \pm 0.18$ to $3.78 \pm 0.18 \mathrm{MPa}$, which could be due to 1) Change in the uniformity of the film network 2) The reduction of intermolecular interactions of pectin, and 3) The formation of microcavities due to entrapment of oil droplets in the continuous polymer matrix [43]. Furthermore, increasing the flexibility and \% E value of film samples by incorporating NEO could be related to the plasticizing effects of the essential oil due to the reduction in intermolecular interactions and increased ductile properties [54]. Accordingly, the liquid form of essential oil at room temperature also facilitated the film deformation and increased the E\% value of the films [55]. Similar results were reported by other researchers [53, 5660]. Obtained results also revealed that the incorporation of CNF and NEO in combination improved the mechanical properties of film samples compared to the control film. Increased UTS and decreased \% $E$ values in this sample could be explained by CNF-NEO interactions that could eliminate the negative effect of NEO on reducing cross-chain interactions. Remarkably, the findings are also in line with the SEM and FTIR results.

\subsection{Water vapor permeability}

WVP values of the film samples are summarized in Table 3. The results showed a significant effect $(p<0.05)$ of the additives on water vapor permeability. Accordingly, as the concentration of CNF increased from 3 to $6 \%$, the WVP values of the films decreased from $3.13 \pm 0.12 \times 10^{-7}$ to $1.02 \pm 0.07 \times 10^{-7} \mathrm{gPa}^{-1} \mathrm{~h}^{-1} \mathrm{~m}^{-1}$, which may be related to 1) The reduction of hydrogen bonds in the film due to electrostatic interactions between CNF and pectin hydroxyl groups that caused the reduction of the water possibility to form 
interactions with free active groups, 2) CNF's structure and its possibility to form intermolecular bonds in a biopolymer, 3 ) Compatibility of CNF with polysaccharide biopolymers and consequently greater affinity to create a continuous network in the biopolymer matrix, 4) Reduction of free spaces in the film matrix due to the pectin-CNF interactions, and 5) The uniform distribution of CNF in the film matrix creates zigzag and tortuous paths for the penetration of water vapor molecules. These results were in accordance with the findings of other researchers $[8,26]$. As found, by increasing the concentration of NEO (1.5 to $3 \%)$, the WVP values of the film samples is increased significantly $\left(3.13 \pm 0.12 \times 10^{-7}\right.$ to $3.66 \pm 0.09 \times 10^{-7} \mathrm{gPa}^{-1} \mathrm{~h}^{-1} \mathrm{~m}^{-1}$ ) due to the destruction of the film matrix and formation of cracks and cavities in the films, which were consistent with the SEM analyzes.

Additionally, essential oils were liquid at room temperature and they can easily deformed in the film structure as well as causing the flexibility and mobility of molecular chains that resulted in better permeability of water molecules through the film [26]. Moreover, high WVP values in the NEO incorporated films could be due to the negative effect of NEO on the pectin intermolecular bonds as well as the formation of micro-cavities in film structure due to the evaporation of essential oils during drying [61]. Crystallization is another important factor affecting the WVP of biopolymers.

Accordingly, more crystalline polymers are less permeable to water vapor due to the continuous structure, [62] which were in line with the XRD and DSC results that showed the reduction in crystallization and increase in WVP value of the OWP based film samples by incorporating NEO. Although the hydrophobicity of essential oils affects the films WVP on the contrary, the physical factors were more effective on the permeability of water vapor in the films. It cannot be assumed that the WVP of films is easily reduced by adding a hydrophobic component to the film formulation, [63] which were similar to previous studies [4, $34,35,61,64,65]$. Results also showed that barrier properties of film samples containing CNF and NEO in combination were improved compared to control and individual NEO incorporated film samples.

According to the results, CNF-NEO interactions increase crystallization and decrease free spaces and free hydroxyl groups in the film matrix, which were resulted in lower hydrophilicity of the films.

\subsection{Antibacterial activity}

The antibacterial activity of the prepared film samples was shown in Table 4. According to the results, the control film had a significant inhibitory effect against both gram-positive (L. monocytogenes, and $S$. aureus) and gram-negative bacteria ( $P$. aeruginosa, E. coli and $S$. enterica) due to the low $\mathrm{pH}$ of the prepared films and the existence of natural antimicrobial compounds such as orange essential oil in OWP. In this regard, orange essential oil contains terpenes, sesquiterpenes, aldehydes, alcohols, esters, hydrocarbons, and oxygenated compounds responsible for antioxidant and antimicrobial properties [66, 67].

According to the obtained results, gram-positive bacteria were more sensitive to the film's natural antimicrobial compounds than gram-negative bacteria due to differences in cell wall structures. Peptidoglycans as well as small proteins are the major components of the cell wall in gram-positive 
bacteria. However, the cell wall of gram-negative bacteria is more complex and it contains various polysaccharides, proteins, lipids, peptidoglycan, as well as an outer membrane that covers the surface of the cell wall and makes it difficult for the active compound to permeate through the cell wall $[53,68]$. The obtained results were in line with findings from previous studies [69, 70].

According to the results, CNF-containing films had no significant inhibitory effect on the different bacterial species used in this study at all tested levels. However, the film samples contained NEO, exhibited antibacterial activity against all tested bacteria, and the antimicrobial activity of the films enhanced significantly $(p<0.05)$ with increasing the concentration of the NEO. As found, the highest antibacterial activity was observed in the OWP /CNF 6\%/ NEO 3\% film sample with inhibition zones of $20.66 \pm 0.57,21.66 \pm 1.52,14.33 \pm 0.57,11.66 \pm 0.57$, and $11.65 \pm 1.52 \mathrm{~mm}$ against $S$. aureus, $L$. monocytogenes, E. coli, S. enterica, and P. aeruginosa, respectively which were similar to the obtained results by other authors $[2,53,71]$.

According to the results E. coli, L. monocytogenes, S. aureus, and P. aeruginosa were the most sensitive bacterial species, respectively, and $S$. enterica was the most resistant to NEO. The antimicrobial activity of nettle essential oil was related to phenol, 2-methyl-5- (1-methylethyl), or carvacrol content [25]. Gul et al. (2012) reported that carvacrol as a monoterpenoid phenol is the major compound of NEO and showed a significant antibacterial, antiviral, antifungal, and antiparasitic effect [25]. Carvacrol destroyed the outer membrane of microorganisms which caused the release of liposaccharides and increased the permeability of the cytoplasmic membrane to ATP and cell death consequently [72]. Additionally, phenolic compounds of NEO could denaturize bacterial enzymes and get bounded with minerals, vitamins and carbohydrates to keep them out of the reach of microorganisms [73].

\section{Conclusion}

Fruit and vegetable wastes have good potential to be converted into bioactive films. Accordingly, cellulose nanofiber and nettle essential oil in different concentrations were successfully used in the preparation of active nanobiocomposite film based on orange waste for the first time. The obtained results showed the compatibility between CNF and NEO with OWP compounds. Moreover, significantly reduced water vapor permeability, \%E values and the increased tensile strength of film samples were shown by increasing the amount of CNF. Compared to the control film, the inclusion of NEO at a concentration of $3 \%$ caused a maximum reduction in tensile strength as well as an increase in melting temperature and water vapor permeability values. SEM results confirmed uniform distribution, improved structure of film samples by the inclusion of CNF, and showed the effect of NEO in the formation of porous structure in film samples. Moreover, films containing CNF and NEO had acceptable thermal and crystalline properties. Additionally, the $T_{g}$ was increased to higher temperatures, and the thermal stability was reduced by incorporating $6 \%$ CNF and $3 \%$ NEO in combination. The obtained results also showed that the OWP film samples had an acceptable antimicrobial effect against five food-borne pathogen bacteria and therefore, the addition of NEO increased the antimicrobial properties of film samples. Moreover, CNF did not exhibit antimicrobial effects. In conclusion, orange juice processing waste is a promising compound for preparing 
biodegradable bioactive films with improved physical, structural, and microbial properties by incorporating CNF and NEO to replace non-biodegradable plastics.

\section{Declarations}

\section{Acknowledgment}

The authors gratefully acknowledge the supports of the Islamic Azad University, Tabriz Branch. This research did not receive any specific grant from funding agencies in the public, commercial, or not-forprofit sectors.

\section{References}

1. Amjadi S, Emaminia S, Nazari M, et al (2019) Application of Reinforced ZnO NanoparticleIncorporated Gelatin Bionanocomposite Film with Chitosan Nanofiber for Packaging of Chicken Fillet and Cheese as Food Models

2. Shojaee-Aliabadi S, Mohammadifar MA, Hosseini H, et al (2014) Characterization of nanobiocomposite kappa-carrageenan film with Zataria multiflora essential oil and nanoclay. Int J Biol Macromol 69:282-289. https://doi.org/10.1016/j.ijbiomac.2014.05.015

3. Vahedikia N, Garavand F, Tajeddin B, et al (2019) Biodegradable zein film composites reinforced with chitosan nanoparticles and cinnamon essential oil: Physical, mechanical, structural and antimicrobial attributes. Colloids Surfaces B Biointerfaces 177:25-32. https://doi.org/10.1016/j.colsurfb.2019.01.045

4. Jouki M, Tabatabaei Yazdi F, Mortazavi SA, Koocheki A (2013) Physical, barrier and antioxidant properties of a novel plasticized edible film from quince seed mucilage. Int J Biol Macromol 62:500507. https://doi.org/10.1016/j.ijbiomac.2013.09.031

5. Karimi N, Alizadeh A, Almasi H, Hanifian S (2020) Preparation and characterization of whey protein isolate/polydextrose-based nanocomposite film incorporated with cellulose nanofiber and $\mathrm{L}$. plantarum: A new probiotic active packaging system. Lwt 121: https://doi.org/10.1016/j.Iwt.2019.108978

6. Zabihollahi N, Alizadeh A, Almasi H, et al (2020) Development and characterization of carboxymethyl cellulose based probiotic nanocomposite film containing cellulose nanofiber and inulin for chicken fillet shelf life extension. Int J Biol Macromol 160:409-417. https://doi.org/10.1016/j.jibiomac.2020.05.066

7. Suttirak W, Manurakchinakorn S (2010) Potential Application of Ascorbic Acid, Citric Acid and Oxalic Acid for Browning Inhibition in Fresh-Cut Fruits and Vegetables. Walailak J Sci Technol 7:5-14. https://doi.org/10.2004/wjst.v7i1.47

8. Viana RM, Sá NMSM, Barros MO, et al (2018) Nanofibrillated bacterial cellulose and pectin edible films added with fruit purees. Carbohydr Polym 196:27-32. 
https://doi.org/10.1016/j.carbpol.2018.05.017

9. Tulamandi S, Rangarajan V, Rizvi SSH, et al (2016) A biodegradable and edible packaging film based on papaya puree, gelatin, and defatted soy protein. Food Packag Shelf Life 10:60-71. https://doi.org/10.1016/j.fpsl.2016.10.007

10. McHugh TH, Senesi E (2000) Apple wraps: A novel method to improve the quality and extend the shelf life of fresh-cut apples. J Food Sci 65:480-485. https://doi.org/10.1111/j.13652621.2000.tb16032.x

11. Mohebbi M, Ansarifar E, Hasanpour N, Amiryousefi MR (2012) Suitability of Aloe Vera and Gum Tragacanth as Edible Coatings for Extending the Shelf Life of Button Mushroom. Food Bioprocess Technol 5:3193-3202. https://doi.org/10.1007/s11947-011-0709-1

12. Razavi SMA, Mohammad Amini A, Zahedi Y (2015) Characterisation of a new biodegradable edible film based on sage seed gum: Influence of plasticiser type and concentration. Food Hydrocoll 43:290-298. https://doi.org/10.1016/j.foodhyd.2014.05.028

13. Seyedi S, Koocheki A, Mohebbi M, Zahedi Y (2014) Lepidium perfoliatum seed gum: A new source of carbohydrate to make a biodegradable film. Carbohydr Polym 101:349-358. https://doi.org/10.1016/j.carbpol.2013.09.072

14. Sothornvit R, Rodsamran P (2008) Effect of a mango film on quality of whole and minimally processed mangoes. 47:407-415. https://doi.org/10.1016/j.postharvbio.2007.08.005

15. Wang X, Sun X, Liu H, et al (2010) Food and Bioproducts Processing Barrier and mechanical properties of carrot puree films. Food Bioprod Process 89:149-156. https://doi.org/10.1016/j.fbp.2010.03.012

16. Bátori V, Jabbari M, Åkesson D, et al (2017) Production of Pectin-Cellulose Biofilms: A New Approach for Citrus Waste Recycling. Int J Polym Sci 2017:. https://doi.org/10.1155/2017/9732329

17. Andrade RMS, Ferreira MSL, Gonçalves ÉCBA (2016) Development and Characterization of Edible Films Based on Fruit and Vegetable Residues. J Food Sci 81:E412-E418. https://doi.org/10.1111/1750-3841.13192

18. FAO (2018) Food and Agriculture Organization of the United Nations Cropping Database. http://www.fao.org/faostat/en/\#data/QC. Accessed 10 Jul 2020

19. Borah PP, Das P, Badwaik LS (2017) Ultrasound treated potato peel and sweet lime pomace based biopolymer film development. Ultrason Sonochem 36:11-19. https://doi.org/10.1016/j.ultsonch.2016.11.010

20. Marín FR, Soler-Rivas C, Benavente-García O, et al (2007) By-products from different citrus processes as a source of customized functional fibres. Food Chem 100:736-741. https://doi.org/10.1016/j.foodchem.2005.04.040

21. Soofi M, Alizadeh A, Hamishehkar H, et al (2021) Preparation of nanobiocomposite film based on lemon waste containing cellulose nanofiber and savory essential oil: A new biodegradable active packaging system. Int J Biol Macromol 169:352-361. https://doi.org/10.1016/j.jibiomac.2020.12.114 
22. Azeredo HMC, Mattoso LHC, Wood D, et al (2009) Nanocomposite edible films from mango puree reinforced with cellulose nanofibers. J Food Sci 74:31-35. https://doi.org/10.1111/j.17503841.2009.01186.x

23. Oun AA, Rhim JW (2015) Preparation and characterization of sodium carboxymethyl cellulose/cotton linter cellulose nanofibril composite films. Carbohydr Polym 127:101-109. https://doi.org/10.1016/j.carbpol.2015.03.073

24. Sherafatkhah Azari S, Alizadeh A, Roufegarinejad L, et al (2020) Preparation and characterization of gelatin/ß-glucan nanocomposite film incorporated with $\mathrm{ZnO}$ nanoparticles as an active food packaging system. J Polym Environ. https://doi.org/10.1007/s10924-020-01950-1

25. Gül S, Emirci B, Başer KH, et al (2012) Chemical composition and in vitro cytotoxic, genotoxic effects of essential oil from urtica dioica L. Bull Environ Contam Toxicol 88:666-671. https://doi.org/10.1007/s00128-012-0535-9

26. Nisar T, Wang ZC, Yang X, et al (2018) Characterization of citrus pectin films integrated with clove bud essential oil: Physical, thermal, barrier, antioxidant and antibacterial properties. Int J Biol Macromol 106:670-680. https://doi.org/10.1016/j.ijbiomac.2017.08.068

27. Šešlija S, Nešić A, Ružić J, et al (2018) Edible blend films of pectin and poly(ethylene glycol): Preparation and physico-chemical evaluation. Food Hydrocoll 77:494-501. https://doi.org/10.1016/j.foodhyd.2017.10.027

28. Szymanska-Chargot M, Zdunek A (2013) Use of FT-IR Spectra and PCA to the Bulk Characterization of Cell Wall Residues of Fruits and Vegetables Along a Fraction Process. Food Biophys 8:29-42. https://doi.org/10.1007/s11483-012-9279-7

29. Ghadetaj A, Almasi H, Mehryar L (2018) Development and characterization of whey protein isolate active films containing nanoemulsions of Grammosciadium ptrocarpum Bioss. essential oil. Food Packag Shelf Life 16:31-40. https://doi.org/10.1016/j.fpsl.2018.01.012

30. Zhang R, Wang W, Zhang H, et al (2019) Effects of hydrophobic agents on the physicochemical properties of edible agar/maltodextrin films. Food Hydrocoll 88:283-290. https://doi.org/10.1016/j.foodhyd.2018.10.008

31. Rajinipriya M, Nagalakshmaiah M, Robert M, Elkoun S (2018) Homogenous and transparent nanocellulosic films from carrot. Ind Crops Prod 118:53-64. https://doi.org/10.1016/j.indcrop.2018.02.076

32. Zykwinska AW, Ralet MCJ, Garnier CD, Thibault JFJ (2005) Evidence for in vitro binding of pectin side chains to cellulose. Plant Physiol 139:397-407. https://doi.org/10.1104/pp.105.065912

33. Shahmohammadi F, Almasi H (2016) Morphological , physical , antimicrobial and release properties of ZnO nanoparticles-loaded bacterial cellulose films. Carbohydr Polym 149:8-19. https://doi.org/10.1016/j.carbpol.2016.04.089

34. Dashipour A, Razavilar V, Hosseini H, et al (2015) Antioxidant and antimicrobial carboxymethyl cellulose films containing Zataria multiflora essential oil. Int J Biol Macromol 72:606-613. https://doi.org/10.1016/j.jibiomac.2014.09.006 
35. Jouki M, Yazdi FT, Mortazavi SA, Koocheki A (2014) Quince seed mucilage films incorporated with oregano essential oil: Physical, thermal, barrier, antioxidant and antibacterial properties. Food Hydrocoll 36:9-19. https://doi.org/10.1016/j.foodhyd.2013.08.030

36. Ghasemlou M, Aliheidari N, Fahmi R, et al (2013) Physical, mechanical and barrier properties of corn starch films incorporated with plant essential oils. Carbohydr Polym 98:1117-1126. https://doi.org/10.1016/j.carbpol.2013.07.026

37. Mahardika M, Abral H, Kasim A, et al (2019) Properties of cellulose nanofiber/bengkoang starch bionanocomposites: Effect of fiber loading. Lwt 116:. https://doi.org/10.1016/j.Iwt.2019.108554

38. Fernandes SCM, Oliveira L, Freire CSR, et al (2009) Novel transparent nanocomposite films based on chitosan and bacterial cellulose. Green Chem 11:2023-2029. https://doi.org/10.1039/b919112g

39. Sun X, Wu Q, Zhang X, et al (2018) Nanocellulose films with combined cellulose nanofibers and nanocrystals: tailored thermal, optical and mechanical properties. Cellulose 25:1103-1115. https://doi.org/10.1007/s10570-017-1627-9

40. Atef M, Rezaei M, Behrooz R (2014) Preparation and characterization agar-based nanocomposite film reinforced by nanocrystalline cellulose. Int J Biol Macromol 70:537-544. https://doi.org/10.1016/j.jibiomac.2014.07.013

41. Valenzuela C, Abugoch L, Tapia C (2013) Quinoa protein-chitosan-sunflower oil edible film: Mechanical, barrier and structural properties. LWT - Food Sci Technol 50:531-537. https://doi.org/10.1016/j.Iwt.2012.08.010

42. Ghanbarzadeh B, Oromiehi AR (2009) Thermal and mechanical behavior of laminated protein films. J Food Eng 90:517-524. https://doi.org/10.1016/j.jfoodeng.2008.07.018

43. Ghanbarzadeh B, Almasi H (2011) Physical properties of edible emulsified films based on carboxymethyl cellulose and oleic acid. Int J Biol Macromol 48:44-49. https://doi.org/10.1016/j.ijbiomac.2010.09.014

44. Sahraee S, Milani JM, Ghanbarzadeh B, Hamishehkar H (2017) Effect of corn oil on physical, thermal, and antifungal properties of gelatin-based nanocomposite films containing nano chitin. LWT - Food Sci Technol 76:33-39. https://doi.org/10.1016/j.Iwt.2016.10.028

45. Pelissari FM, Andrade-Mahecha MM, Sobral PJ do A, Menegalli FC (2017) Nanocomposites based on banana starch reinforced with cellulose nanofibers isolated from banana peels. J Colloid Interface Sci 505:154-167. https://doi.org/10.1016/j.jcis.2017.05.106

46. Alemdar A, Sain M (2008) Biocomposites from wheat straw nanofibers: Morphology, thermal and mechanical properties. Compos Sci Technol 68:557-565. https://doi.org/10.1016/j.compscitech.2007.05.044

47. Petersson L, Oksman K (2006) Biopolymer based nanocomposites: Comparing layered silicates and microcrystalline cellulose as nanoreinforcement. Compos Sci Technol 66:2187-2196. https://doi.org/10.1016/j.compscitech.2005.12.010

48. Ghanbarzadeh B, Almasi H, Entezami AA (2010) Physical properties of edible modified starch/carboxymethyl cellulose films. Innov Food Sci Emerg Technol 11:697-702. 
https://doi.org/10.1016/j.ifset.2010.06.001

49. Huq T, Salmieri S, Khan A, et al (2012) Nanocrystalline cellulose (NCC) reinforced alginate based biodegradable nanocomposite film. Carbohydr Polym 90:1757-1763.

https://doi.org/10.1016/j.carbpol.2012.07.065

50. Reddy JP, Rhim JW (2014) Characterization of bionanocomposite films prepared with agar and paper-mulberry pulp nanocellulose. Carbohydr Polym 110:480-488.

https://doi.org/10.1016/j.carbpol.2014.04.056

51. Shankar S, Rhim JW (2016) Preparation of nanocellulose from micro-crystalline cellulose: The effect on the performance and properties of agar-based composite films. Carbohydr Polym 135:18-26. https://doi.org/10.1016/j.carbpol.2015.08.082

52. Alizadeh-Sani M, Khezerlou A, Ehsani A (2018) Fabrication and characterization of the bionanocomposite film based on whey protein biopolymer loaded with TiO2 nanoparticles, cellulose nanofibers and rosemary essential oil. Ind Crops Prod 124:300-315. https://doi.org/10.1016/j.indcrop.2018.08.001

53. Shojaee-Aliabadi S, Hosseini H, Mohammadifar MA, et al (2013) Characterization of antioxidantantimicrobial k-carrageenan films containing Satureja hortensis essential oil. Int J Biol Macromol 52:116-124. https://doi.org/10.1016/j.ijbiomac.2012.08.026

54. Ramos M, Jiménez A, Peltzer M, Garrigós MC (2012) Characterization and antimicrobial activity studies of polypropylene films with carvacrol and thymol for active packaging. J Food Eng 109:513519. https://doi.org/10.1016/j.jfoodeng.2011.10.031

55. Fabra MJ, Talens P, Chiralt A (2008) Tensile properties and water vapor permeability of sodium caseinate films containing oleic acid-beeswax mixtures. J Food Eng 85:393-400. https://doi.org/10.1016/j.jfoodeng.2007.07.022

56. Haq MA, Hasnain A, Jafri FA, et al (2016) Characterization of edible gum cordia film: Effects of beeswax. LWT - Food Sci Technol 68:674-680. https://doi.org/10.1016/j.Iwt.2016.01.011

57. Hromiš NM, Lazić VL, Markov SL, et al (2015) Optimization of chitosan biofilm properties by addition of caraway essential oil and beeswax. J Food Eng 158:86-93.

https://doi.org/10.1016/j.jfoodeng.2015.01.001

58. Jamróz E, Juszczak L, Kucharek M (2018) Investigation of the physical properties, antioxidant and antimicrobial activity of ternary potato starch-furcellaran-gelatin films incorporated with lavender essential oil. Int J Biol Macromol 114:1094-1101. https://doi.org/10.1016/j.jibiomac.2018.04.014

59. Moradi M, Tajik H, Razavi Rohani SM, et al (2012) Characterization of antioxidant chitosan film incorporated with Zataria multiflora Boiss essential oil and grape seed extract. LWT - Food Sci Technol 46:477-484. https://doi.org/10.1016/j.Iwt.2011.11.020

60. Sánchez-González L, Chiralt A, González-Martínez C, Cháfer M (2011) Effect of essential oils on properties of film forming emulsions and films based on hydroxypropylmethylcellulose and chitosan. J Food Eng 105:246-253. https://doi.org/10.1016/j.jfoodeng.2011.02.028 
61. Ahmad M, Benjakul S, Prodpran T, Agustini TW (2012) Physico-mechanical and antimicrobial properties of gelatin film from the skin of unicorn leatherjacket incorporated with essential oils. Food Hydrocoll 28:189-199. https://doi.org/10.1016/j.foodhyd.2011.12.003

62. Miller KS, Krochta JM (1997) Oxygen and aroma barrier properties of edible films: A review. Trends Food Sci Technol 8:228-237. https://doi.org/10.1016/S0924-2244(97)01051-0

63. Hosseini MH, Razavi SH, Mousavi MA (2009) Antimicrobial, physical and mechanical properties of chitosan-based films incorporated with thyme, clove and cinnamon essential oils. J Food Process Preserv 33:727-743. https://doi.org/10.1111/j.1745-4549.2008.00307.x

64. Atef M, Rezaei M, Behrooz R (2015) Characterization of physical, mechanical, and antibacterial properties of agar-cellulose bionanocomposite films incorporated with savory essential oil. Food Hydrocoll 45:150-157. https://doi.org/10.1016/j.foodhyd.2014.09.037

65. Espitia PJP, Avena-Bustillos RJ, Du WX, et al (2014) Physical and antibacterial properties of açaí edible films formulated with thyme essential oil and apple skin polyphenols. J Food Sci 79:. https://doi.org/10.1111/1750-3841.12432

66. Espinosa-Pardo FA, Nakajima VM, Macedo GA, et al (2017) Extraction of phenolic compounds from dry and fermented orange pomace using supercritical $\mathrm{CO} 2$ and cosolvents. Food Bioprod Process 101:1-10. https://doi.org/10.1016/j.fbp.2016.10.002

67. Gonçalves D, Teschke MEE, Koshima CC, et al (2015) Fractionation of orange essential oil using liquid-liquid extraction: Equilibrium data for model and real systems at $298.2 \mathrm{~K}$. Fluid Phase Equilib 399:87-97. https://doi.org/10.1016/j.fluid.2015.04.022

68. Pranoto Y, Rakshit SK, Salokhe VM (2005) Enhancing antimicrobial activity of chitosan films by incorporating garlic oil, potassium sorbate and nisin. LWT - Food Sci Technol 38:859-865. https://doi.org/10.1016/j.Iwt.2004.09.014

69. Gülay Kirbaşlar F, Tavman A, Dülger B, Türker G (2009) Antimicrobial activity of Turkish Citrus peel oils. Pakistan J Bot 41:3207-3212

70. Kivanç M, Akgül A (1986) Antibacterial activities of essential oils from Turkish spices and citrus. Flavour Fragr J 1:175-179. https://doi.org/10.1002/ffj.2730010409

71. Hosseini SF, Rezaei M, Zandi M, Farahmandghavi F (2015) Bio-based composite edible films containing Origanum vulgare L. essential oil. Ind Crops Prod 67:403-413. https://doi.org/10.1016/j.indcrop.2015.01.062

72. Cosentino S, Tuberoso CIG, Pisano B, et al (1999) In-vitro antimicrobial activity and chemical composition of Sardinian Thymus essential oils. Lett Appl Microbiol 29:130-135. https://doi.org/10.1046/j.1472-765X.1999.00605.x

73. Khan JA, Hanee S (2011) Antibacterial properties of Punica granatum peels. Int J Appl Biol Pharm Technol 2:23-27

\section{Tables}


Table 1. The fabricated Orange Waste-based bioactive film samples.

\begin{tabular}{|llll|}
\hline Samples & OWP (\% w/v) & CNF (\% w/v) & NEO (\% w/v) \\
\hline OWP/CNF 0\%/NEO 0\% & 6 & - & - \\
\hline OWP /CNF 0\%/ NEO 1.5\% & 6 & - & 1.5 \\
\hline OWP /CNF 0\%/ NEO 3\% & 6 & - & 3 \\
\hline OWP /CNF 3\%/ NEO 0\% & 6 & 3 & - \\
\hline OWP /CNF 3\%/ NEO 1.5\% & 6 & 3 & 1.5 \\
\hline OWP /CNF 3\%/ NEO 3\% & 6 & 3 & 3 \\
\hline OWP /CNF 6\%/ NEO 0\% & 6 & 6 & - \\
\hline OWP /CNF 6\%/ NEO 1.5\% & 6 & 6 & 1.5 \\
\hline OWP /CNF 6\%/ NEO 3\% & 6 & 6 & 3 \\
\hline
\end{tabular}

OWP: Orange Waste Powder, CNF: cellulose nanofiber, NEO: Nettle essential oil.

Table 2. Thermal properties of Orange Waste -based bioactive film samples.

\begin{tabular}{|lcl|}
\hline Samples & $\mathrm{T}_{\mathrm{g}}\left({ }^{\circ} \mathrm{C}\right)$ & $\mathrm{T}_{\mathrm{m}}\left({ }^{\circ} \mathrm{C}\right)$ \\
\hline OWP /CNF 0\%/ NEO 0\% & -87.9 & 125.7 \\
\hline OWP /CNF 6\%/ NEO 0\% & -86.6 & 152.9 \\
\hline OWP /CNF 0\%/ NEO 3\% & -98.9 & 158.0 \\
\hline OWP /CNF 6\%/ NEO 3\% & -87.7 & 126.1 \\
\hline
\end{tabular}

OWP: Orange Waste Powder, CNF: cellulose nanofiber, NEO: Nettle essential oil, $\mathrm{T}_{\mathrm{g}}$ : glass transition temperature and $T_{m}:$ melting temperature.

Table 3. Thickness and mechanical properties Orange Waste -based bioactive film samples. 


\begin{tabular}{|llll|}
\hline Samples & UTS (MPa) & \multicolumn{1}{c}{ EB (\%) } & WVP $\left(\times 10-7 \mathrm{gPa}^{-1} \mathrm{~h}^{-1} \mathrm{~m}^{-1}\right)$ \\
\hline OWP /CNF 0\%/NEO 0\% & $4.88 \pm 0.10^{\mathrm{g}}$ & $32.40 \pm 0.36^{\mathrm{c}}$ & $3.13 \pm 0.12^{\mathrm{c}}$ \\
\hline OWP /CNF 0\%/ NEO 1.5\% & $4.38 \pm 0.18^{\mathrm{h}}$ & $34.03 \pm 0.75^{\mathrm{b}}$ & $3.35 \pm 0.07^{\mathrm{b}}$ \\
\hline OWP /CNF 0\%/ NEO 3\% & $3.78 \pm 0.18^{\mathrm{i}}$ & $36.09 \pm 0.61^{\mathrm{a}}$ & $3.66 \pm 0.09^{\mathrm{a}}$ \\
\hline OWP /CNF 3\%/ NEO 0\% & $6.20 \pm 0.10^{\mathrm{d}}$ & $27.81 \pm 0.55^{\mathrm{f}}$ & $2.18 \pm 0.17^{\mathrm{f}}$ \\
\hline OWP /CNF 3\%/ NEO 1.5\% & $5.86 \pm 0.23^{\mathrm{e}}$ & $29.51 \pm 0.69^{\mathrm{e}}$ & $2.47 \pm 0.09^{\mathrm{e}}$ \\
\hline OWP /CNF 3\%/ NEO 3\% & $5.38 \pm 0.21^{\mathrm{f}}$ & $31.31 \pm 0.34^{\mathrm{d}}$ & $2.85 \pm 0.14^{\mathrm{d}}$ \\
\hline OWP /CNF 6\%/ NEO 0\% & $7.66 \pm 0.29^{\mathrm{a}}$ & $20.94 \pm 0.81^{\mathrm{i}}$ & $1.02 \pm 0.07^{\mathrm{i}}$ \\
\hline OWP /CNF 6\%/ NEO 1.5\% & $7.35 \pm 0.10^{\mathrm{b}}$ & $22.79 \pm 0.43^{\mathrm{h}}$ & $1.37 \pm 0.12^{\mathrm{h}}$ \\
\hline OWP /CNF 6\%/ NEO 3\% & $6.75 \pm 0.08^{\mathrm{c}}$ & $24.75 \pm 0.50^{\mathrm{g}}$ & $1.68 \pm 0.10^{\mathrm{g}}$ \\
\hline
\end{tabular}

Data are expressed as mean \pm standard deviation $(n=3)$ and different letters show significant difference at the $5 \%$ level in Duncan's test ( $<<0.05)$; OWP: Orange Waste Powder, CNF: cellulose nanofiber, NEO: Nettle essential oil, EB: elongation at break, UTS: ultimate tensile strength.

Table 4. Inhibition zones produced by different film types on tested bacteria 


\begin{tabular}{|c|c|c|c|c|c|}
\hline \multirow[t]{2}{*}{ Samples } & \multicolumn{5}{|c|}{$\begin{array}{l}\text { Inhibition zone }(\mathrm{mm}) \text { of films } \\
\text { Tested bacteria }\end{array}$} \\
\hline & S. aureus & $\begin{array}{l}\text { L. } \\
\text { monocytogenes }\end{array}$ & E. coli & S. enterica & $\begin{array}{l}P . \\
\text { aeroginosa }\end{array}$ \\
\hline $\begin{array}{l}\text { OWP /CNF 0\%/NEO } \\
0 \%\end{array}$ & $\begin{array}{l}10.33 \pm \\
1.52^{\mathrm{c}}\end{array}$ & $10.33 \pm 1.15^{c}$ & ND & $\begin{array}{l}7.33 \pm \\
0.57^{c}\end{array}$ & $\begin{array}{l}3.00 \pm \\
1.41^{\mathrm{c}}\end{array}$ \\
\hline $\begin{array}{l}\text { OWP /CNF 0\%/ NEO } \\
1.5 \%\end{array}$ & $\begin{array}{l}16.00 \pm \\
2.00^{\mathrm{b}}\end{array}$ & $16.33 \pm 0.57^{b}$ & $\begin{array}{l}7.66 \pm \\
1.52^{\mathrm{b}}\end{array}$ & $\begin{array}{l}9.66 \pm \\
0.57^{b}\end{array}$ & $\begin{array}{l}7.33 \pm \\
0.57^{\mathrm{b}}\end{array}$ \\
\hline $\begin{array}{l}\text { OWP /CNF 0\%/ NEO } \\
3 \%\end{array}$ & $\begin{array}{l}20.66 \pm \\
0.57^{\mathrm{a}}\end{array}$ & $21.66 \pm 1.52^{a}$ & $\begin{array}{l}14.33 \pm \\
0.57^{\mathrm{a}}\end{array}$ & $\begin{array}{l}11.66 \pm \\
0.57^{\mathrm{a}}\end{array}$ & $\begin{array}{l}11.66 \pm \\
1.52^{\mathrm{a}}\end{array}$ \\
\hline $\begin{array}{l}\text { OWP /CNF 3\%/ NEO } \\
0 \%\end{array}$ & $\begin{array}{l}10.66 \pm \\
1.52^{c}\end{array}$ & $10.00 \pm 1.00^{c}$ & ND & $\begin{array}{l}7.66 \pm \\
1.15^{\mathrm{c}}\end{array}$ & $\begin{array}{l}3.66 \pm \\
2.08^{c}\end{array}$ \\
\hline $\begin{array}{l}\text { OWP /CNF } 3 \% / \text { NEO } \\
1.5 \%\end{array}$ & $\begin{array}{l}16.33 \pm \\
1.52^{\mathrm{b}}\end{array}$ & $15.66 \pm 1.52^{b}$ & $\begin{array}{l}7.33 \pm \\
2.08^{b}\end{array}$ & $\begin{array}{l}9.33 \pm \\
0.57^{\mathrm{b}}\end{array}$ & $\begin{array}{l}7.66 \pm \\
1.52^{\mathrm{b}}\end{array}$ \\
\hline $\begin{array}{l}\text { OWP /CNF 3\%/ NEO } \\
3 \%\end{array}$ & $\begin{array}{l}20.33 \pm \\
2.08^{a}\end{array}$ & $20.66 \pm 2.08^{a}$ & $\begin{array}{l}15.33 \pm \\
2.51^{\mathrm{a}}\end{array}$ & $\begin{array}{l}11.33 \pm \\
0.57^{a}\end{array}$ & $\begin{array}{l}11.33 \pm \\
0.57^{a}\end{array}$ \\
\hline $\begin{array}{l}\text { OWP /CNF 6\%/ NEO } \\
0 \%\end{array}$ & $\begin{array}{l}10.00 \pm \\
1.00^{c}\end{array}$ & $10.00 \pm 2.00^{c}$ & ND & $\begin{array}{l}7.33 \pm \\
1.15^{\mathrm{c}}\end{array}$ & $\begin{array}{l}3.33 \pm \\
1.15^{\mathrm{c}}\end{array}$ \\
\hline $\begin{array}{l}\text { OWP /CNF } 6 \% / \text { NEO } \\
1.5 \%\end{array}$ & $\begin{array}{l}16.33 \pm \\
2.08^{\mathrm{b}}\end{array}$ & $16.66 \pm 1.52^{b}$ & $\begin{array}{l}8.00 \pm \\
2.64^{b}\end{array}$ & $\begin{array}{l}9.33 \pm \\
0.57^{b}\end{array}$ & $\begin{array}{l}8.00 \pm \\
1.00^{\mathrm{b}}\end{array}$ \\
\hline $\begin{array}{l}\text { OWP /CNF 6\%/ NEO } \\
3 \%\end{array}$ & $\begin{array}{l}21.33 \pm \\
0.57^{a}\end{array}$ & $22.33 \pm 2.51^{a}$ & $\begin{array}{l}15.33 \pm \\
1.15^{\mathrm{a}}\end{array}$ & $\begin{array}{l}11.66 \pm \\
1.52^{\mathrm{a}}\end{array}$ & $\begin{array}{l}11.66 \pm \\
0.57^{a}\end{array}$ \\
\hline
\end{tabular}

Data are expressed as mean \pm standard deviation $(n=3)$ and different letters show significant difference at the $5 \%$ level in Duncan's test $(p<0.05)$; ND: Not determined; OWP: Orange waste powder, CNF: cellulose nanofiber, NEO: Nettle essential oil.

\section{Figures}




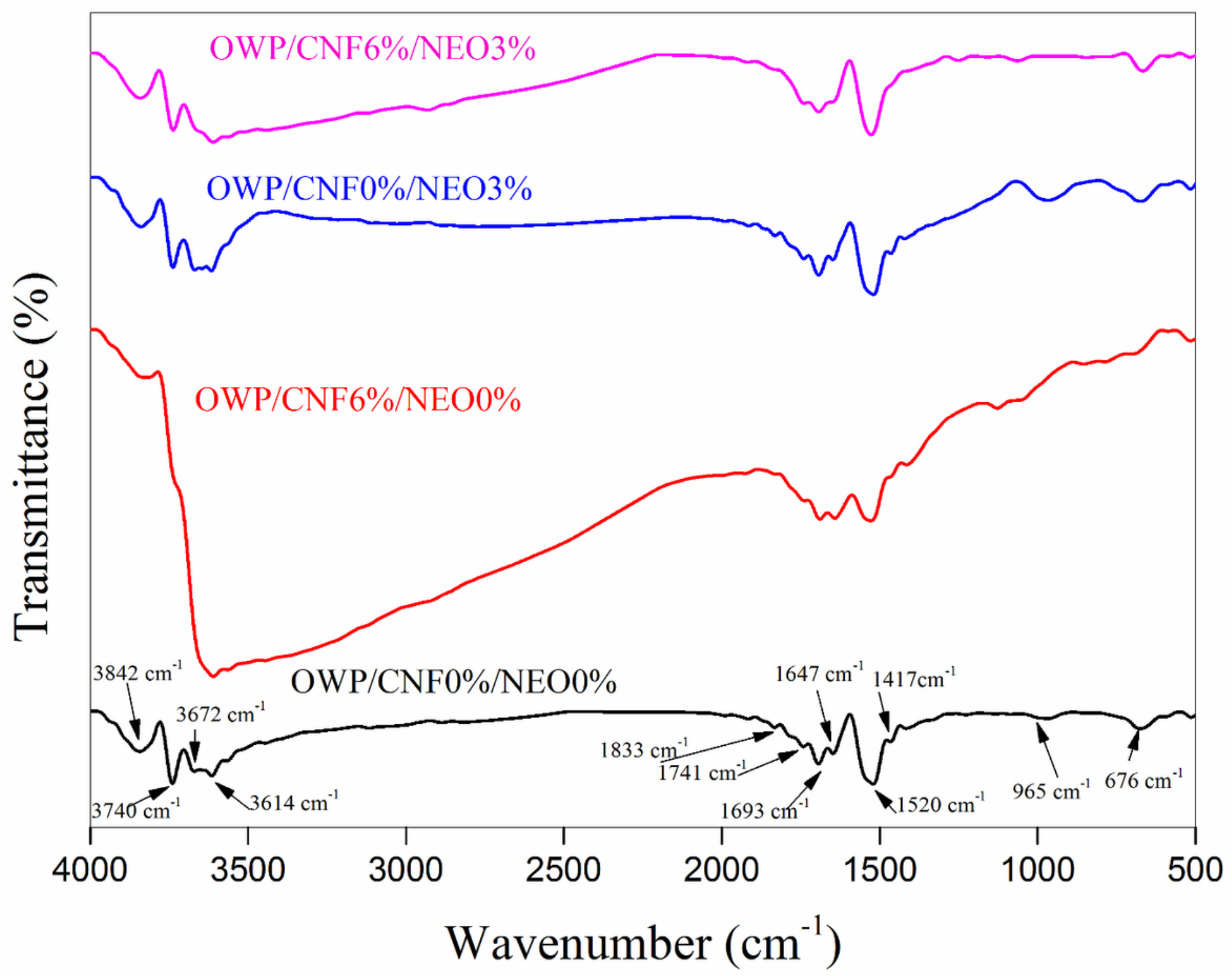

Figure 1

Fourier transforms infrared (FT-IR) spectra of OWP/CNF0\%/NEO0\%, OWP /CNF0\%/NEO3\%, OWP/CNF6\%/NEOO and OWP /CNF6\%/NEO3\% nanobiocomposite film samples. OWP: Orange Waste powder, CNF: cellulose nanofiber, NEO: Nettle essential oil. 

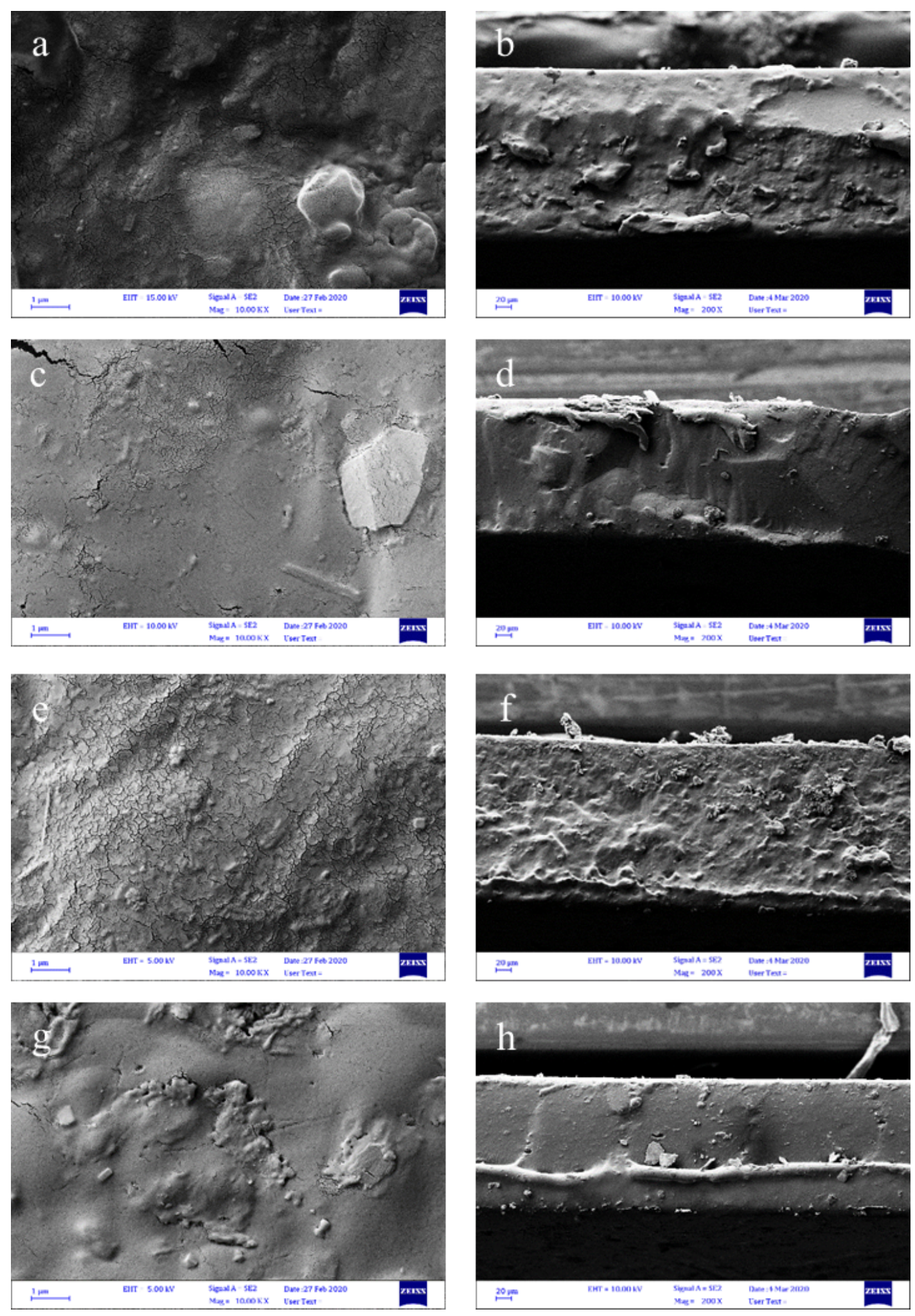

\section{Figure 2}

Field emission scanning electron microscopy (FE-SEM) images of surface and cross section of OWP/CNF0\%/NEO0\% (a and b), OWP/CNF6\%/NEO0\% (c and d), OWP/CNF0\%/NEO3\% (e and $f$ ) and OWP/CNF6\%/NEO3\% ( $\mathrm{g}$ and $\mathrm{h}$ ) nanobiocomposite film samples OWP: Orange Waste powder, CNF: cellulose nanofiber, NEO: Nettle essential oil. 


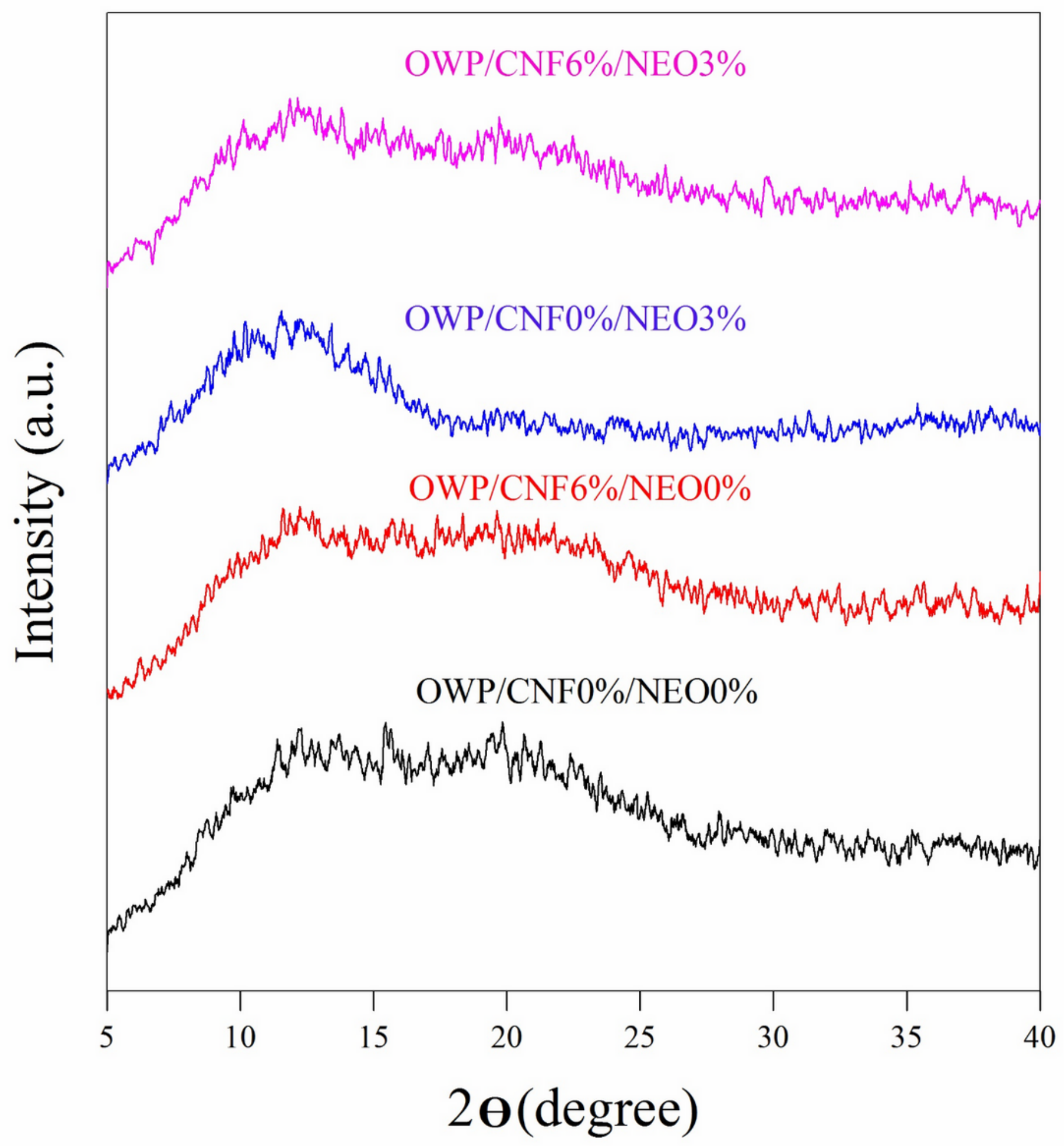

Figure 3

X-ray diffraction (XRD) patterns OWP/CNF0\%/NEO0\%, OWP/CNF0\%/NEO3\%, OWP/CNF6\%/NEO0\% and OWP/CNF6\%/NEO3\% nanobiocomposite film samples. OWP: Orange Waste powder, CNF: cellulose nanofiber, NEO: Nettle essential oil. 